\title{
Optimization of extraction conditions of flavonoid compounds from Thyme (Thymus vulgaris Libiatae)
}

\author{
Yunjin Park $^{1} \cdot$ Jumi Lee ${ }^{1} \cdot$ Man-Jin In $^{2} \cdot$ Hee Jeong Chae ${ }^{1}$ \\ 타임으로부터의 플라보노이드 화합물의 추출 조건 최적화
}

박윤진 ${ }^{1} \cdot$ 이주미 ${ }^{1} \cdot{\text { 인 } \text { 만진 }^{2} \text { - 채희정 }}^{1}$

Received: 14 January 2020 / Accepted: 13 March 2020 / Published Online: 31 March 2020

(C) The Korean Society for Applied Biological Chemistry 2020

\begin{abstract}
Total polyphenol contents, flavonoid contents, 1,1diphenyl-2-picrylhydrazyl (DPPH) free radical scavenging activities of ethanol extracts of 20 herbal plants (sage, turmeric, mace, bayleaf, fenugreek, oregano, blackpepper, whitepepper, clove, marjoram, cinnamon, coriander, basil, dillseed, mustard, cadamon, thyme, celery, rosemary, cumin) were analyzed for the screening of high flavonoid-containing plant resource. Thyme extract, showing the highest flavonoid content and a high degree of antioxidant activity, was selected as a bioactive cosmetic material. The total polyphenols and flavonoids contents of thyme extracts were measured as $6.90 \mathrm{mg}$ chlorogenic acid equivalent (CAE)/ $100 \mathrm{~g}$ and $1.71 \mathrm{mg}$ naringin equivalent $(\mathrm{NE}) / 100 \mathrm{~g}$, respectively, and DPPH radical scavenging activities was $90 \%$. Among the tested organic solvents, hexane gave the highest extraction yield. Thus hexane was selected as the most suitable solvent for the extraction of thyme. Response surface method was used to obtain optimized extraction conditions for thyme: reaction temperature of $35.9{ }^{\circ} \mathrm{C}$, raw material to hexane ratio of $1.63: 25(\mathrm{w} / \mathrm{v})$, and reaction time of $192 \mathrm{~min}$. These predicted extraction conditions
\end{abstract}

Hee Jeong Chae $(\triangle)$

E-mail:hjchae@hoseo.edu

${ }^{1}$ Department of Food and Pharmaceutical Engineering \& Institute of Basic Science, Hoseo University, Asan 31499, Republic of Korea

${ }^{2}$ Department of Chemical Engineering, Chungwoon University, Incheon 22100, Republic of Korea

This is an Open Access article distributed under the terms of the Creative Commons Attribution Non-Commercial License (http://creativecommons. org/licenses/by-nc/3.0/) which permits unrestricted non-commercial use, distribution, and reproduction in any medium, provided the original work is properly cited. was validated by a total flavonoid extraction experiment showing a value equivalent to $96.3 \%$ of the predicted total flavonoid content. It is expected that the optimized solvent extraction conditions could be used for the production of flavonoid using thyme.

Keywords Extraction conditions - Flavonoid - Optimization Response surface method - Thyme (Thymus vulgaris Libiatae)

\section{서 론}

허브는 오랫동안 식용 향신료와 약용으로 사용되어 왔으며, 항 균, 항산화, 항염증 등의 생리활성을 갖는 성분을 많이 함유하 고 있음이 꾸준히 보고되고 있다[1-3]. 세계적으로 허브의 생리 활성 성분을 활용한 일반식품, 건강기능식품, 화장품 등의 제품 이 증가하고 있으며, 국내에서도 허브의 생리활성 규명 및 활 용에 관한 탐구가 지속적으로 연구되고 있다[4,5].

허브의 대표적인 생리활성 물질인 폴리페놀(polyphenol)은 벤 젠고리의 수소원자 하나가 수산기로 치환된 물질인 페놀이 두 개 이상 결합된 화합물을 말하며 벤젠고리의 수소가 두개 이상 의 수산기로 치환된 화합물이다. 화합물의 구조에 따라 phenolic acid, flavonoids, stilbenes, lignan 및 tannins 등으로 분류된다.

폴리페놀과 함께 허브류의 대표적인 생리활성 물질인 플라보 노이드는 두개의 벤젠고리와 헤테로 사이클릭 고리로 구성된 것 을 기본형으로 한 화합물로 quercetin, catechin, isoflavone 등이 알려져 있다[6]. 플라보노이드는 세포 내 lipoxygenase 활성에 의한 산화 생성물 및 자유라디칼 생성 속도 저해[7], 세포신호 전달 과정에 관여하는 효소의 활성을 저해함으로써 염증 반응 저해 및 억제 등의 효과[8]를 갖는 것으로 알려져 있다. 밀싹 
및 민들레 등 식물 유래 플라보노이드 제조를 위한 최적화 연 구는 진행되었으나 $[9,10]$, 타임을 이용한 플라보노이드 추출공정 에 대한 연구가 보고된 바 없다.

허브 중 타임(Thymus vulgaris Labiatae)은 목본 식물로서 꿀 풀과에 속하며 항균, 항산화 작용을 가지고 있어 고대부터 민 간요법에서 사용되어온 자원이다. 타임의 주요 생리활성 성분은 thymol, carvacrol, geraniol, $p$-cymene이며[11], 타임의 정유 성 분에 대한 항산화, 항염증, 항노화, 항균에 대한 연구가 보고된 바 있다[11,12]. 또한 국내에서 자생하거나 재배되는 타임의 서 식지에 따른 활성 비교, 추출용매에 따른 유효성분 분석 등의 연구가 보고되어 있다[13,14].

타임의 활용은 주로 타임의 항균과 항산화 활성을 이용하는 것으로 김치, 육포 등의 제조에 타임 추출물을 첨가하여 식품 의 조직감과 저장성을 향상시킨 연구 $[15,16]$, 타임 추출물이 첨 가된 세척수를 항갈변제로 사용하여 양상추 등의 신선식품의 저 장성을 향상시킨 연구[17], 화장품의 천연 방부제로서 활용한 연구[18], 소금물 존재 하에서 연강(mild steel)의 부식 저해제로 사용한 연구[19] 등 다양한 분야에서의 활용 연구가 보고된 바 있다. 식품뿐만 아니라 다양한 분야로 타임의 용도를 확대하기 위하여 폴리페놀이나 플라보노이드 등의 생리활성 성분을 다량 함유하고 있는 추출물의 제조가 매우 중요하다. 타임의 추출에 관한 연구로는 물 또는 유기용매로 환류 냉각 추출방법[14,20] 이 보고된 바 있고, 초임계 추출과 같은 새로운 추출법에 대한 연구도 진행되고 있다[20].

본 연구에서는 허브 식물로부터 생리활성 성분을 추출하기 위한 연구의 일환으로 오랫동안 사용되어 온 20 종의 허브 식물 로부터 추출물을 제조하고 폴리페놀과 플라보노이드 함량, 항산 화 활성을 비교하여 이 중 플라보노이드 추출수율이 높은 타임 을 선별하였다. 또한 타임으로부터 플라보노이드 추출 수율을 비교하여 최적의 추출 용매를 선정하고, 실험계획법으로 타임 플라보노이드의 추출 조건을 최적화함으로서 향후 타임 추출물 의 생산에 관한 기초적인 자료를 확보하고자 하였다.

\section{재료 및 방법}

\section{재료}

본 실험에 사용한 허브 원료는 모두 (주)이에스기술연구소(군포, 대한민국)에서 건조 분말을 구입하여 원료 표준화를 위해 분쇄 한 후 입도 $500 \mu \mathrm{m}$ 이하의 것만을 추출용 시료로 사용하였다.

\section{허브 추출물 제조}

겨자(mustard), 계피(cinnamon), 딜씨드(dillseed), 로즈마리 (rosemary), 마조람(marjoram), 메이스(mace), 바질(basil), 백후추 (white pepper), 샐러리(celery), 세이지(sage), 월계수 잎(bay leaf), 오레가노(oregano), 카다몬(cadamon), 커민(cumin), 코리안 더(coriander), 클러브(clove), 타임(thyme), 튜메릭(turmeric), 페 뉴그릭(fenugreek), 흑후추(black pepper)의 20가지 건조 분말에 각각 $1: 20(\mathrm{w}: \mathrm{v})$ 비율로 $80 \%$ ethanol $(\mathrm{v} / \mathrm{v})$ 을 혼합한 후 30 ${ }^{\circ} \mathrm{C}$ 에서 2 시간 동안 진탕추출하였다. 추출액을 원심분리 $(1,600 \times \mathrm{g}$, 10 분) 후 상등액을 취해 감압여과(Whatman, Buckinghamshire, $\mathrm{UK}$ )한 다음 감압농축 및 동결건조하여 dimethyl sulfoxide
(DMSO)에 녹인 후 분석용 시료로 사용하였다. 동결건조 시료 는 deep freezer에 보관하였으며, 시료는 $1 \mathrm{mg} / \mathrm{mL}$ 농도로 제조 하여 실험을 진행하였다.

\section{추출용매 선정을 위한 타임추출물의 제조}

타임 분말과 증류수, 에탄올, 메탄올, $n$-헥산을 각각 $1: 25(\mathrm{w}: \mathrm{v})$ 의 비율로 혼합하여 4 시간 동안 $25^{\circ} \mathrm{C}$ 에서 진탕추출하였다. 추 출액을 원심분리 $(1,600 \times \mathrm{g}, 20$ 분 $)$ 하여 상등액을 취하고 감압여과 (Whatman, Buckinghamshire, UK)한 다음 진공농축한 후 동일 부피만큼 에탄올을 가하여 총 플라보노이드 함량을 분석하였다. 분석 실험은 3 회 반복하여 측정하였다.

\section{반웅표면분석법을 이용한 추출조건 최적화}

타임 분말의 플라보노이드 추출조건 최적화를 위한 실험을 반 응표면분석법(response surface method, RSM)의 하나인 중심합 성계획법(central composite design)으로 설계하였다. 독립변수 $(\mathrm{Xn})$ 는 추출온도 $\left(\mathrm{X}_{1}\right)$, 시료농도 $\left(\mathrm{X}_{2}\right)$, 추출시간 $\left(\mathrm{X}_{3}\right)$ 을 각각 $-1,0$, 1 의 3 가지 범위로 추출조건을 계획하였으며(Table 1), 총 플라 보노이드 함량 $\left(\mathrm{Y}_{1}\right)$ 으로 종속변수 $(\mathrm{Yn})$ 를 설계하였다. 실험모델 설 계는 Design Expert 6.0 (Stat-Ease Inc,. Minneapolis, MN, USA)를 사용하였다.

\section{총 폴리페놀 함량 분석}

총 폴리페놀 함량은 Folin-Denis 방법[21]에 의해 측정하였다. $0.1 \mathrm{~mL}$ 의 시료에 $0.05 \mathrm{~mL}$ 의 Folin-Ciocalteu phenol reagent를 혼합 후 4 분간 방치시키고, $20 \%$ 의 $\mathrm{Na}_{2} \mathrm{CO}_{3} 1.5 \mathrm{~mL}$ 를 가하여 2 분간 반응시킨 다음 $760 \mathrm{~nm}$ 에서 흡광도를 측정하여 총 폴리페 놀 함랑을 계산하였다. 표준물질로는 chlorogenic acid를 사용하 였으며, 함량은 추출물 $\mathrm{g}$ 당 chlorogenic acid equivalent (CAE) 로 나타냈다.

\section{총 플라보노이드 함량 분석}

Hwang 등[22]의 방법을 응용하여 총 플라보노이드 함량을 분 석하였다. $0.5 \mathrm{~mL}$ 의 시료와 $5 \mathrm{~mL}$ 의 diethylene glycol을 혼합한 다음 $0.5 \mathrm{~mL} 1 \mathrm{~N} \mathrm{NaOH}$ 를 추가하여 1 시간 동안 $37^{\circ} \mathrm{C}$ 에서 반 응시킨 다음 흡광도를 $420 \mathrm{~nm}$ 에서 측정하여 총 플라보노이드 함량을 계산하였다. 표준물질로는 naringin을 사용하였으며, 추 출물 $\mathrm{g}$ 당 naringin equivalent(NE)로 함량을 나타냈다.

\section{DPPH radical 소거능 측정}

$\mathrm{DPPH}$ radical 소거능은 Blois의 방법[23]을 일부 변형하여 분석 하였다. 시료 $40 \mu \mathrm{L}$ 와 메탄올에 $0.4 \mathrm{mM}$ 의 농도로 용해한 $1,1-$ diphenyl-2-picrylhydrazy (DPPH) 용액 $160 \mu \mathrm{L}$ 를 혼합한 다음 30 분간 차광상태에서 반응시킨 후 microplate reader (VERSAmax,

Table 1 Independent variable values and their corresponding levels for experimental design

\begin{tabular}{ccccc}
\hline \hline \multirow{2}{*}{ Factor } & \multirow{3}{*}{ Unit } & \multicolumn{3}{c}{ Variable level } \\
\cline { 3 - 5 } & & -1 & 0 & 1 \\
\hline Temperature & ${ }^{\circ} \mathrm{C}$ & 25 & 50 & 75 \\
Concentrations & $\%$ & 0.50 & 1.25 & 2.00 \\
Time & Min & 30 & 135 & 240 \\
\hline
\end{tabular}


Table 2 Total polyphenol contents, total flavonoid contents and DPPH free radical scavenging activities of ethanol extracts of various herbal plants

\begin{tabular}{|c|c|c|c|c|c|}
\hline Common name & $\begin{array}{l}\text { Scientific } \\
\text { name }\end{array}$ & $\begin{array}{l}\text { Extraction yields } \\
\qquad \%)\end{array}$ & $\begin{array}{l}\text { Total polyphenol contents } \\
\qquad(\mathrm{mg} \text { CAE } / 100 \mathrm{~g})^{1)}\end{array}$ & $\begin{array}{l}\text { Total flavonoid contents } \\
\quad(\mathrm{mg} \mathrm{NE} / 100 \mathrm{~g})^{2)}\end{array}$ & $\begin{array}{c}\text { DPPH free radical } \\
\text { scavenging activities } \\
(\%)\end{array}$ \\
\hline Mustard & Brassica juncea & 8.89 & $4.07 \pm 0.11$ & $0.33 \pm 0.01$ & $1.05 \pm 1.17$ \\
\hline Cinnamon & Cinnamomum verum & 5.18 & $3.35 \pm 0.18$ & $0.13 \pm 0.09$ & $90.46 \pm 1.86$ \\
\hline Dillseed & Anethum graveolens & 3.53 & $0.18 \pm 0.0004$ & $0.06 \pm 0.02$ & $4.73 \pm 2.99$ \\
\hline Rosemary & Salvia rosmarinus & 7.51 & $4.88 \pm 0.01$ & $0.80 \pm 0.01$ & $95.16 \pm 0.88$ \\
\hline Marjoram & Origanum majorana & 10.55 & $5.33 \pm 0.4$ & $0.94 \pm 0.18$ & $90.86 \pm 0.32$ \\
\hline Mace & Myristica fragrans & 9.44 & $1.97 \pm 0.06$ & $-3)$ & $16.19 \pm 2.50$ \\
\hline Basil & Ocimum basilicum & 9.06 & $1.84 \pm 0.03$ & $0.33 \pm 0.07$ & $86.71 \pm 1.74$ \\
\hline White pepper & Piper nigrum L. & 0.23 & - & - & - \\
\hline Celery & Apium graveolens & 7.22 & $4.12 \pm 0.03$ & $0.50 \pm 0.07$ & $48.09 \pm 3.82$ \\
\hline Sage & Salvia officinalis & 6.76 & $3.64 \pm 0.03$ & $0.57 \pm 0.10$ & $93.41 \pm 0.27$ \\
\hline Bay leaf & Laurus nobilis & 10.14 & $4.36 \pm 0.06$ & $0.42 \pm 0.06$ & $93.23 \pm 1.94$ \\
\hline Oregano & Origanum vulgare & 7.20 & $3.44 \pm 0.03$ & $0.77 \pm 0.03$ & $91.91 \pm 0.30$ \\
\hline Cadamom & Elettaria cardamomum & 4.25 & $0.63 \pm 0.01$ & $0.013 \pm 0.009$ & $4.07 \pm 5.34$ \\
\hline Cumin & Cuminum cyminum & 7.46 & $0.51 \pm 0.01$ & $0.34 \pm 0.03$ & $19.71 \pm 4.34$ \\
\hline Coriander & Coriandrum sativum & 8.43 & $0.29 \pm 0.01$ & - & $4.61 \pm 0.16$ \\
\hline Clove & Syzygium aromaticum & 9.44 & $7.08 \pm 0.23$ & $0.97 \pm 0.05$ & $97.59 \pm 0.85$ \\
\hline Thyme & Thymus vulgaris & 9.52 & $6.90 \pm 0.02$ & $1.71 \pm 0.19$ & $93.14 \pm 0.23$ \\
\hline Turmeric & Curcuma longa & 5.17 & $0.07 \pm 0.004$ & $0.05 \pm 0.01$ & $65.86 \pm 2.87$ \\
\hline Fenugreek & Trigonella foenumgraecum & 5.60 & $1.22 \pm 0.01$ & $0.40 \pm 0.08$ & - \\
\hline Black pepper & Piper nigrum $\mathrm{L}$ & 5.49 & - & - & $1.05 \pm 1.82$ \\
\hline
\end{tabular}

${ }^{1)}$ Total polyphenol content analyzed as chlorogenic acid equivalent (CAE) $\mathrm{mg} / 100 \mathrm{~g}$ of extract

${ }^{2)}$ Total flavonoid content analyzed as naringin equivalent $(\mathrm{NE}) \mathrm{mg} / 100 \mathrm{~g}$ of extract

3)-: Not detected

Molecular Device LLC, San Jose, CA, USA)로 $515 \mathrm{~nm}$ 에서 의 흡광도를 측정하였다. DPPH radical 소거능은 [1-(시료구/무 첨가 대조구) $] \times 100$ 으로 계산하였다.

\section{결과 및 고찰}

\section{식물 추출물 제조 및 활성비교}

$80 \%$ 에탄올을 이용하여 20 가지의 허브 식물을 추출하였다. $80 \%$ 에탄올은 극성과 비극성의 성질을 모두 가진 양친매성 용매로, 에탄올 수용액의 형태는 식물체 내부로 침투가 용이하여 페놀 성 물질의 추출에 유리한 특징을 가지고 있다[24]. 추출액을 감 압농축한 후 동결건조하고 $\mathrm{DMSO}$ 에 $1 \mathrm{mg} / \mathrm{mL}$ 의 농도가 되도록 녹여 총 폴리페놀과 총 플라보노이드 및 $\mathrm{DPPH}$ radical 소거활 성을 측정하였다. 각 허브 원료로부터 에탄올 추출의 고형분 수 율을 고려하여 총 폴리페놀과 총 플라보노이드의 함량을 Table 2에 표시하였다. Table 2에서 보는 바와 같이 총 폴리페놀 함 량은 클러브, 타임, 로즈마리, 계피의 순으로 각각 $7.08,6.90$, $4.88,3.35 \mathrm{mg} \mathrm{CAE} / 100 \mathrm{~g}$ 을 나타냈으며, 총 플라보노이드 함량 은 타임, 오레가노, 로즈마리, 클러브의 순으로 $1.71,0.77,0.80$, $0.97 \mathrm{mg} \mathrm{NE} / 100 \mathrm{~g}$ 을 나타냈다. 또한, DPPH radical 소거활성은 타임, 월계수 잎, 세이지, 클러브, 오레가노, 마조람, 바질, 계피, 로즈마리 추출물에서 $90 \%$ 이상의 높은 항산화 활성을 보였다. 총 플라보노이드 함량은 타임 추출물에서 가장 높았으며, 총 폴
리페놀 함량 및 DPPH radical 소거활성도 타임 추출물에서 높 은 수준을 보여 20 가지 허브 식물 중 타임을 추출시료로, 플라 보노이드를 추출 화합물로 선택하였다. 시판되는 6 종의 허브류 중에서 로즈마리 추출물의 폴리페놀 함량이 높다는 보고[25]와 11 종의 허브 중 배초향, 페퍼민트 등의 DPPH radical 소거활성 이 우수하다는 보고[26]가 있다. 추출용매(열수 혹은 메탄올)와 시료의 차이에 의한 차이를 고려하더라도 폴리페놀이나 플라보 노이드와 같은 생리활성 물질의 함량이 높은 추출물이 높은 항 산화활성을 보인 것[27]과 유사한 경향이었다.

\section{타임의 추출 조건 최적화}

타임 분말로부터 플라보노이드 추출을 위한 적절한 용매 선정 을 위해 물과 순도 $99 \%$ 이상의 용매(에탄올, 메탄올, $n$-헥산)로 각각 타임 추출물을 제조하여 플라보노이드 함량을 분석하였다. 타임이 함유하고 있는 플라보노이드계 물질의 극성 및 비극성 도를 고려하여 극성이 다른 세 용매를 사용하여 추출하였다. 그 결과 Fig. 1에서 보는 바와 같이, 에탄올, 메탄올 및 $n$-헥산 추 출물의 총 플라보노이드 함량은 $2.86 \pm 0.64,2.09 \pm 0.30$ 및 $10.09 \pm 1.24 \mathrm{mg} \mathrm{NE} / 100 \mathrm{~g}$ 이었고, 물 추출물에서는 검출되지 않 았다. 그러므로 총 플라보노이드 함량이 높은 용매인 $n$-헥산을 추출용매로 선정하였다. 플라보노이드의 추출에 고온의 물을 용 매로도 사용하나[28] 본 연구에서는 비교적 낮은 온도인 $25^{\circ} \mathrm{C}$ 에서 추출하여 플라보노이드가 검출되지 않은 것으로 판단된다. 타임 분말로부터 $n$-헥산을 이용하여 플라보노이드를 추출하 


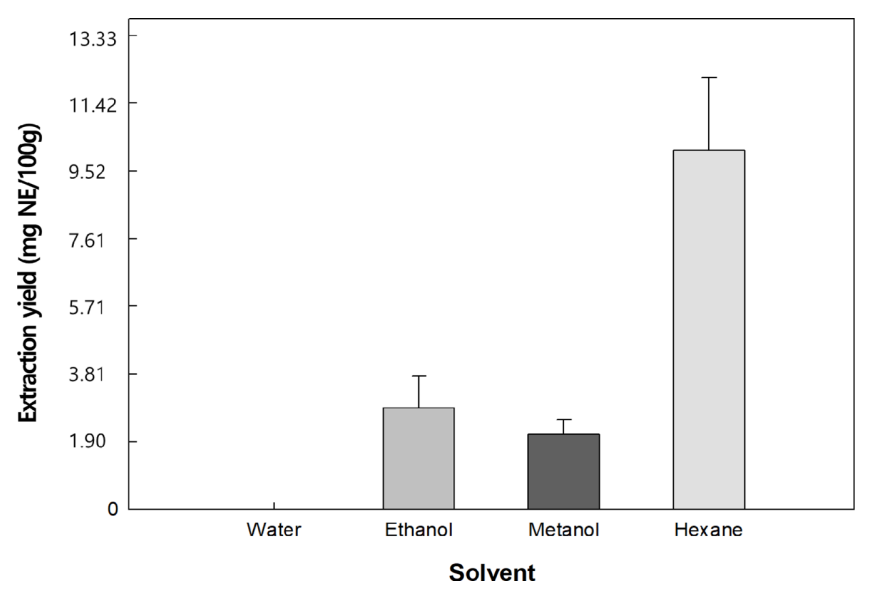

Fig. 1 The extraction yields of flavonoid from thyme using different solvent

기 위한 최적의 조건을 찾기 위하여 반응표면분석법 $(\mathrm{RSM})$ 을 사 용하였다. 독립변수로서 추출온도 $\left(\mathrm{X}_{1}\right)$, 시료농도 $\left(\mathrm{X}_{2}\right)$ 및 추출시 간 $\left(\mathrm{X}_{3}\right)$ 을 선정하였고, 종속변수로서 총 플라보노이드 함량 $\left(\mathrm{Y}_{1}\right)$ 을 선정하였다. 독립변수를 3 가지 범위 $(-1,0,1)$ 에서 20 가지 조 건으로 추출실험을 실시하여 추출물의 총 플라보노이드 함량을 분석하였다. 독립변수의 최소값과 최대값은 식물 추출물의 스크 리닝 실험 조건 및 용매의 끓는점을 고려하여 설정하였다. 그 결과 Table 3 에서 보는 바와 같이, 각 실험 조건에서 총 플라 보노이드 함량은 3.73-7.41 mg NE/100 g 범위로 분석되었다. 다음 식은 각 추출조건에 따른 추출물의 총 플라보노이드 함량 에 대한 반응표면 회귀식이다.

$\mathrm{Y}_{1}=+69.95-2.42 \mathrm{X}_{1}+9,03 \mathrm{X}_{2}+4.34 \mathrm{X}_{3}-3.61 \mathrm{X}^{2}-9.55 \mathrm{X}^{2}-4.74 \mathrm{X}^{2}{ }^{2}$ $1.42 \mathrm{X}_{1} \mathrm{X}_{2}-1.75 \mathrm{X}_{1} \mathrm{X}_{3}-0.27 \mathrm{X}_{2} \mathrm{X}_{3}$

$n$-헥산 추출물의 총 플라보노이드에 대한 회귀식의 상관관계 $\left(\mathrm{R}^{2}\right)$ 는 0.9011 로, $5 \%$ 이내의 수준에서 유의성이 인정되었다. ANOVA 분산분석으로 독립변수에 대한 종속변수의 상호관계를
확인한 결과, 독립변수 중에서 추출온도 $\left(\mathrm{X}_{1}\right)$ 를 제외한 추출농도 $\left(\mathrm{X}_{2}\right)$ 와 추출시간 $\left(\mathrm{X}_{3}\right)$ 이 유의성이 있는 것으로 나타났다 $(5 \%$ 의 유 의수준 이내). 능선분석 그래프를 통해 3 가지 인자의 상호관계 를 확인하였으며, 추출농도 $\left(\mathrm{X}_{2}\right)$ 가 $0.50-1.63 \%$ 로 증가할수록 총 플라보노이드 함량이 유의성 있게 증가하는 것으로 확인되었다 $(p<0.0003)$. 추출시간 $\left(\mathrm{X}_{3}\right)$ 은 $30-193$ 분으로 증가할수록 총 플라 보노이드 함량이 유의적으로 증가하였다 $(p<0.0227)$. 총 플라보 노이드 함량에 대한 추출온도 $\left(\mathrm{X}_{1}\right)$ 의 영향은 미미하였으나 추출 농도 $\left(\mathrm{X}_{2}\right)$ 는 $1.63 \%$ 까지 증가하여 총 플라보노이드 함량은 뚜렷 하게 증가하는 경향을 보였다(Fig. 2). 타임의 일종인 섬백리향 에서 $75 \%$ 에탄올을 용매로 microwave를 이용한 항산화 성분 의 추출조건 최적화에 관한 연구에서도 본 연구와 동일하게 플 라보노이드 추출량의 추출시간은 $5 \%$ 유의수준에서 유의한 것 으로 보고되었다[29].

\section{최적 추출조건 예측 및 검중}

타임으로부터 온도, 농도, 시간의 추출조건에 따른 총 플라보노 이드 함량의 반응표면분석에서 예측된 총 플라보노이드 함량은 $7.05 \mathrm{mg} \mathrm{NE} / 100 \mathrm{~g}$ 이었고, 이 때의 추출조건은 추출온도 35.87 ${ }^{\circ} \mathrm{C}$, 추출농도 $1.63 \%$, 추출시간 192.28 분이었다. 예측된 조건으 로 타임 $n$-헥산 추출물을 제조한 후 플라보노이드 함량을 분석 한 결과 $6.79 \pm 0.46 \mathrm{mg} \mathrm{NE} / 100 \mathrm{~g}$ 로 예측 값의 $96.3 \%$ 를 나타내 어 실험계획법에 의한 추출조건 최적화의 신뢰성이 검증되었다. 이상의 최적화된 조건에서 얻은 타임 $n$-헥산 추출물의 총 플 라보노이드 함량은 Kwon 등의 연구[29]에서 마이크로파 투입 조건에서 $75 \%$ 에탄올로 추출한 추출물에서의 함량 $(15.08 \mathrm{mg}$ $\mathrm{NE} / 100 \mathrm{~g}$ ) 보다는 낮은 수치이나, 마이크로파를 사용하지 않은 열수추출물 $\left(80-100{ }^{\circ} \mathrm{C}, 3.5\right.$ 시간 추출)을 대상으로 한 연구[30]에 비하면 크게 향상된 것이다. 또한 총 폴리페놀과 총 플라보노 이드 함량은 물론 항산화 활성 모두 높은 $(+)$ 의 상관관계를 나 타낸 연구 결과[31]와 유사한 결과이다. 결론적으로 본 연구에 서 최적화한 추출 조건은 플라보노이드의 생산을 위한 타임의 용매추출 조건으로서 활용할 수 있을 것으로 기대된다.
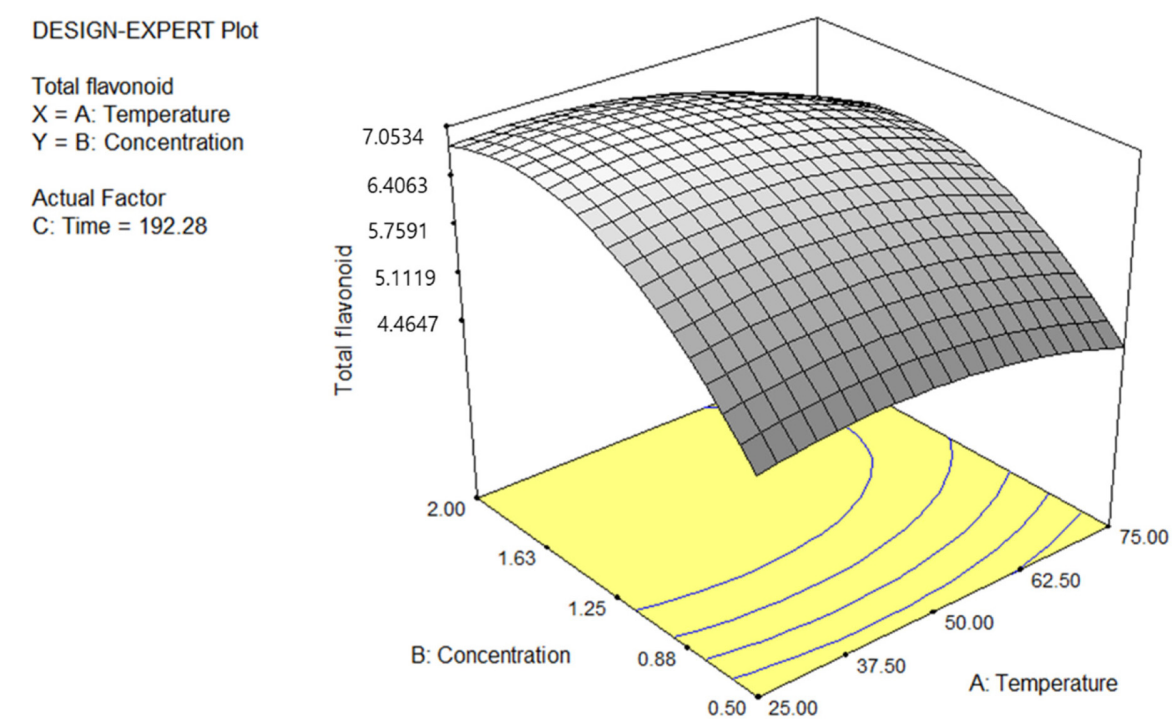

Fig. 2 Interaction graphs of temperature, time and thyme concentrations in extraction of total flavonoid from thyme 
Table 3 Design layout in RSM-cental composite design for flavonoid extraction conditions

\begin{tabular}{|c|c|c|c|c|c|}
\hline \multirow{2}{*}{$\begin{array}{l}\text { Exp. } \\
\text { No. }\end{array}$} & \multirow{2}{*}{ Type } & \multicolumn{3}{|c|}{ Independent variables } & \multirow{2}{*}{$\frac{\text { Response }}{\text { Total flavonoid }(\mathrm{mg} \mathrm{NE} / 100 \mathrm{~g})^{1)}}$} \\
\hline & & Temperature $\left({ }^{\circ} \mathrm{C}\right)$ & Concentrations $(\%)$ & Time (min) & \\
\hline 1 & Fact & $75(1)$ & $0.5(-1)$ & $240(1)$ & 4.15 \\
\hline 2 & Fact & $25(-1)$ & $0.5(-1)$ & $240(1)$ & 4.56 \\
\hline 3 & Fact & $75(1)$ & $2(1)$ & $240(1)$ & 5.34 \\
\hline 4 & Fact & $50(0)$ & $1.25(0)$ & $135(0)$ & 6.69 \\
\hline 5 & Fact & $25(-1)$ & $2(1)$ & $30(-1)$ & 5.57 \\
\hline 6 & Fact & $75(1)$ & 2(1) & $30(-1)$ & 5.29 \\
\hline 7 & Fact & $25(-1)$ & $0.5(-1)$ & $30(-1)$ & 3.73 \\
\hline 8 & Fact & $50(0)$ & $1.25(0)$ & $135(0)$ & 6.74 \\
\hline 9 & Center & $50(0)$ & $1.25(0)$ & $135(0)$ & 6.30 \\
\hline 10 & Center & $25(-1)$ & $2(1)$ & $240(0)$ & 6.32 \\
\hline 11 & Center & $75(1)$ & $0.5(-1)$ & $30(-1)$ & 3.96 \\
\hline 12 & Center & $50(0)$ & $1.25(0)$ & $135(0)$ & 6.40 \\
\hline 13 & Axial & $75(1)$ & $1.25(0)$ & $135(0)$ & 5.94 \\
\hline 14 & Axial & $25(-1)$ & $1.25(0)$ & $135(0)$ & 6.79 \\
\hline 15 & Axial & $50(0)$ & $1.25(0)$ & $30(-1)$ & 5.10 \\
\hline 16 & Axial & $50(0)$ & $0.5(-1)$ & $135(0)$ & 4.56 \\
\hline 17 & Axial & $50(0)$ & $1.25(0)$ & $135(0)$ & 6.86 \\
\hline 18 & Axial & $50(0)$ & $1.25(0)$ & $240(1)$ & 7.41 \\
\hline 19 & Center & $50(0)$ & $1.25(0)$ & $135(0)$ & 6.97 \\
\hline 20 & Center & $50(0)$ & $2(1)$ & $135(0)$ & 7.04 \\
\hline
\end{tabular}

${ }^{1)}$ Total flavonoid content analyzed as naringin equivalent (NE) $\mathrm{mg} / 100 \mathrm{~g}$ of extract

Table 4 ANOVA analysis of the model for the extraction conditions of flavonoid from thyme

\begin{tabular}{cccc}
\hline \hline Source & DF & F-value & Prob $>\mathrm{F}$ \\
\hline Model & 9 & 227.88 & 0.0015 \\
$\mathrm{X}_{1}{ }^{\mathbf{1}}$ & 1 & 58.52 & 0.1604 \\
$\mathrm{X}_{2}{ }^{2)}$ & 1 & 814.91 & 0.0003 \\
$\mathrm{X}_{3}{ }^{3)}$ & 1 & 188.30 & 0.0227 \\
$\mathrm{X}_{1} \mathrm{X}_{2}$ & 1 & 0.64 & 0.4441 \\
$\mathrm{X}_{1} \mathrm{X}_{3}$ & 1 & 0.98 & 0.3483 \\
$\mathrm{X}_{2} \mathrm{X}_{3}$ & 1 & 0.024 & 0.8805 \\
\hline
\end{tabular}

${ }^{1)} \mathrm{X}_{1}$ : extraction temperature $\left({ }^{\circ} \mathrm{C}\right)$

${ }^{2)} \mathrm{X}_{2}$ : extraction concentrations (\%)

${ }^{3)} \mathrm{X}_{3}$ : extraction time (min)

\section{초 록}

타임, 바질, 로즈마리 등 20 종의 허브 식물에 대한 $80 \%$ 에탄올 추 출물의 항산화 활성을 분석하였다. 탐색 대상 허브 식물 중 타임 추출물의 총 폴리페놀 함량은 $6.90 \pm 0.02 \mathrm{mg} \mathrm{CAE} / 100 \mathrm{~g}$ 로 높은 값 을 보였으며, 총 플라보노이드 함량은 $1.71 \pm 0.19 \mathrm{mg} \mathrm{NE} / 100 \mathrm{~g}$ 으로 가장 높았다. 또한 DPPH radical 소거능은 $93.14 \pm 0.23 \%$ 로 매 우 높은 수준의 항산화 활성을 나타냈다. 타임으로부터 플라보 노이드를 추출하기 위하여 용매로서 물, 에탄올, 메탄올, 헥산
중 추출수율이 높은 헥산을 추출용매로 선정하였다. 반응표면분 석법을 이용하여 타임 추출물의 최적화 추출조건으로 추출온도 는 $35.9{ }^{\circ} \mathrm{C}$, 농도는 $1.63 \%$, 시간은 192 분이었다. 예측된 조건으 로 제조한 타임 $n$-헥산 추출물의 총 플라보노이드 함량은 예측 값의 $96.3 \%$ 로 반응표면분석법에 의한 추출조건 최적화의 신뢰 성이 검증되었다. 이상의 최적화된 추출 조건은 플라보노이드의 생산을 위한 타임의 용매추출 조건으로서 활용할 수 있을 것으 로 기대된다.

Keywords 반응표면분석법 - 최적화 - 추출조건 · 타임(Thymus vulgaris Libiatae) · 플라보노이드

감사의 글 본 논문은 제 1 저자의 "타임 추출물의 나노 에멀젼 제조 및 화장 품 바이오소재로서의 생리활성” 석사학위논문을 바탕으로 작성되었습니다.

\section{References}

1. Ryoo JW, Cha BC (1998) Mineral content and antioxidative activity in some herb plants. J Korean Medicinal Crop Sci 6: 28-32

2. Chung HY, Kim HB (2000) in vitro studies on the superoxide scavenging activities, the cytotoxic and the immunomodulating effects of thirteen kinds of herbal extracts. J Korean Food Sci Technol 32: 699-705

3. Choi IY, Bae YI, Shim KH (2010) DPPH radical scavenging effect and antimicrobial activities of some herbal extracts. J Korean Hort Sci Technol 28: 871-876

4. Chorianopoulos N, Kalpoutzakis E, Aligiannis N, Mitaku S, Nychas GJ, 
Haroutounian SA (2004) Essential oils of satureja, origanum, and thymus species: chemical composition and antibacterial activities against foodborne pathogens. J Agric Food Chem 52: 8261-8267

5. Park MH, Kim DY, Jang HJ, Jo YH, Jeong JT, Lee DY, Baek MI, Ryu HW, Oh SR (2019) Analysis of polyphenolic metabolites from Artemisia gmelinii Weber ex Stechm. and regional comparison in Korea. J Appl Biol Chem 62: 433-439

6. Kim HR (2016) Optimization of Polyphenol Extraction from Fruit and Non-edible Parts of Aronia melanocarpa and Biological Activity Evaluation. Master's thesis, Hoseo University

7. Hu HN, Huang Y, Xiong MR, Luo SF, Chen Y (2006) The effects of natural flavonoids on lipoxygenase-mediated oxidation of compounds with a benzen ring structure-A new possible mechanism of flavonoids anti-chemical carcinogenesis and other toxicities. Int J Toxicol 25: 295301

8. Moutsatsou P (2007) The spectrum of phytoestrogens in nature: our knowledge is expanding. Hormones (Athens) 6: 173-193

9. Lee SB, Wang X, Yoon BH (2018) Optimization of total flavonoids extraction process from wheat sprout using central composite design model. Appl Chem Eng 29: 446-451

10. Han KH, Jang HS, Hong IG (2019) Optimization of antioxidant extraction from dandelion (Taraxacum officinale) leaves using BBDRSM. Appl Chem Eng 4: 408-414

11. Tohidi B, Rahimmalek M, Arzani A (2017) Essential oil composition, total phenolic, flavonoid contents, and antioxidant activity of Thymus species collected from different regions of Iran. Food Chem 220: 153 161

12. Cosentino S, Tuberoso CIG, Pisano B, Satta M, Mascia V, Arzedil E, Palmas F (1999) In-vitro antimicrobial activity and chemical composition of Sardinian thymus essential oils. Lett Appl Microbiol 29: 130-135

13. Young HK, Lee JC, Choi YH (1994) Essential oils of Thymus quinquecostatus Celakov and Thymus magnus Nakai. J Korean Medicinal Crop Sci 2: 234-240

14. Baik JA, Baek YH, Chiang MH (2009) Phenol contents of solvent extraction in several domestic Thymus quinquecostatus Celak. J BioEnviron Control 18: 468-474

15. Kim MK, Kim OM, Kim ID, Kim MH, Park IK, Kang MS, Lee NH, Kim SD (1998) The effects of water extracts from thyme (Thymus vulgaris L.) and tarragon (Artemisia dracuncculus L.) on shelf life and quality of kimchi. Korean J Postharvest Sci Technol 5: 49-56

16. Lee SJ, Park GS (2004) The quality characteristics of beef jerky prepared with various spices. Korean J Food Cookery Sci 20: 489-497
17. Lee HJ, Luo J, Choi JY, Moon KD (2018) Effect of thyme extract on quality characteristics of fresh-cut lettuce during storage. Korean J Food Preserv 25: 304-310

18. KU JE, Han HS, Song JH (2013) The recent trend of the natural preservative used in cosmetics. Korean J Aesthet Cosmetol 11: 835-844

19. Premkumar P, Kannan K, Natesan M (2008) Thyme extract of Thymus vulgar L. as volatile corrosion inhibitor for mild steel in $\mathrm{NaCl}$ environment. Asian J Chem 20: 445-451

20. Simandi B, Hajdu V, Peredi K, Czukor B, Nobik-Kovacs A, Kery A (2001) Antioxidant activity of pilot-plant alcoholic and supercritical carbon dioxide extracts of thyme. Eur J Lipid Sci Technol 103: 355-358

21. Folin O, Denis W (1912) On phosphotungstic-phosphomolybdic compounds as color reagents. J Biol Chem 12: 239-243

22. Hwang SJ, Yoon WB, Lee OH, Cha SJ, Kim DJ (2014) Radicalscavenging-linked antioxidant activities of extracts from black chokeberry and blueberry cultivated in Korea Food Chem 146: 71-77

23. Blois MS (1958) Antioxidant determination by the use of a stable free radical. Nature 181: 1199-1200

24. Kim KC, Kim JS (2019) Physiological activity of the extract from Dolwoe (Gynostemma pentaphyllum Makino) leaves tea by different ethanol concentrations. J Plant Biotechnol 46: 37-44

25. Chae IG, Kim HJ, Yu MH, Kim HI, Lee IS (2010) Antioxidant and antibacterial activity of commercially available herbs in Korean markets. J Korean Soc Food Sci Nutr 39: 1411-1417

26. Choi IY, Song YJ, Lee WH (2010) DPPH radical scavenging effect and antimicrobial activities of some herbal extracts. Korean J Hort Sci Technol 28: 871-876

27. Kim EJ, Choi JY, Yu MR, Kim MY, Lee SH, Lee BH (2012) Total polyphenols, total flavonoid contents, and antioxidant activity of Korean natural and medicinal plants. Korean J Food Sci Technol 44: 337-342

28. Zhoh CK, Kwon HJ, Ahn SR (2010) Antioxidative and antimicrobial effects to skin flora of extracts from peel of Allium cepa L. Korean J Aesthet Cosmetol 8: 49-58

29. Kwon YJ, Noh JE, Lee JE, Lee SH, Choi YH, Kwon JH (2005) Prediction of optimal extraction conditions in microwave-assisted process for antioxidant-related components from Thymus quinquecostatus. Korean J Food Preserv 12: 344-349

30. Kim IS, Yang MR, Lee OH, Kang SN (2011) Antioxidant activities of hot water extracts from various spices. Int J Mol Sci 12: 4120-4131

31. Kim EY, Baik IH, Kim JH, Kim SR, Rhyu MR (2004) Screening of the antioxidant activity of some medicinal plants. Korean J Food Sci Technol 36: 333-338 